\title{
Novel systemic therapies in atopic dermatitis: what do we need to fulfil the promise of a treatment revolution? [version
}

\section{1; peer review: 3 approved]}

\author{
Helen Alexander(i1), Thomas Patton², Zarif K. Jabbar-Lopez¹, Andrea Manca², \\ Carsten Flohr ${ }^{1}$ \\ 1 Unit for Population-Based Dermatology Research, St John's Institute of Dermatology, Guy's and St Thomas' NHS Foundation Trust \\ and King's College London, London, UK \\ ${ }^{2}$ Centre for Health Economics, University of York, York, UK
}

V1 First published: 31 Jan 2019, 8(F1000 Faculty Rev):132

https://doi.org/10.12688/f1000research.17039.1

Latest published: 31 Jan 2019, 8(F1000 Faculty Rev):132

https://doi.org/10.12688/f1000research.17039.1

\begin{abstract}
Patients with atopic dermatitis (AD) who do not adequately respond to topical therapy and phototherapy often need systemic immunomodulatory treatment to control their symptoms. Conventional systemic agents, such as ciclosporin, azathioprine, and methotrexate, have been used for decades, but there are concerns about their safety profile. There are now many novel systemic agents emerging through clinical trials, which may have great potential in the treatment of $A D$. Despite this, there are very few data comparing the performance of these drugs against each other. The purpose of this article is to review the current systemic therapies in $A D$ and present an indirect comparison of systemic $A D$ treatments using effectiveness and safety data from published randomised controlled trials, highlighting important remaining gaps in knowledge. Although the latest developments in systemic AD treatments are exciting and dearly needed, further work is required before the promise of a therapeutic revolution becomes reality.
\end{abstract}

\section{Keywords}

Atopic dermatitis, eczema

\section{Open Peer Review \\ Approval Status \\ 1 \\ 2 \\ 3 \\ version 1 \\ 31 Jan 2019 \\ Faculty Reviews are review articles written by the prestigious Members of Faculty Opinions. The articles are commissioned and peer reviewed before publication to ensure that the final, published version is comprehensive and accessible. The reviewers who approved the final version are listed with their names and affiliations.}

1. Robert Sidbury, Seattle Children's Hospital, Seattle, USA

2. Gil Yosipovitch, Miller School of Medicine, University of Miami, Miami, USA

3. Steven R Feldman, Wake Forest School of Medicine, Winston-Salem, USA

Any comments on the article can be found at the end of the article. 
Corresponding author: Helen Alexander (helen.2.alexander@kcl.ac.uk)

Author roles: Alexander H: Conceptualization, Formal Analysis, Investigation, Methodology, Visualization, Writing - Original Draft Preparation, Writing - Review \& Editing; Patton T: Writing - Original Draft Preparation, Writing - Review \& Editing; Jabbar-Lopez ZK: Methodology, Writing - Original Draft Preparation, Writing - Review \& Editing; Manca A: Supervision, Writing - Original Draft Preparation, Writing - Review \& Editing; Flohr C: Conceptualization, Formal Analysis, Methodology, Project Administration, Supervision, Visualization, Writing - Original Draft Preparation, Writing - Review \& Editing

Competing interests: CF has received investigator-led research funding from Sanofi for microbiome work. His department has received clinical trial funding from Sanofi and AbbVie to test novel therapeutics in paediatric atopic eczema patients. The views expressed are those of the authors and not necessarily those of the UK National Health Service, the UK Department of Health, or the National Institute of Health Research. HA, TP, AM, and ZKJ-L declare that they have no competing interests.

Grant information: CF is funded through a UK National Institute for Health Research (NIHR) Career Development Fellowship (CDF-201407-037). CF, HA, and ZKJ-L are supported by the NIHR Biomedical Research Centre based at Guy's and St Thomas' NHS Foundation Trust and King's College London.

The funders had no role in study design, data collection and analysis, decision to publish, or preparation of the manuscript.

Copyright: (c) 2019 Alexander $\mathrm{H}$ et al. This is an open access article distributed under the terms of the Creative Commons Attribution License, which permits unrestricted use, distribution, and reproduction in any medium, provided the original work is properly cited.

How to cite this article: Alexander $\mathrm{H}$, Patton T, Jabbar-Lopez ZK et al. Novel systemic therapies in atopic dermatitis: what do we need to fulfil the promise of a treatment revolution? [version 1; peer review: 3 approved] F1000Research 2019, 8(F1000 Faculty Rev):132 https://doi.org/10.12688/f1000research.17039.1

First published: 31 Jan 2019, 8(F1000 Faculty Rev):132 https://doi.org/10.12688/f1000research.17039.1 


\section{Introduction}

Atopic dermatitis (AD) affects $15-30 \%$ of children and $5 \%$ of adults and carries profound functional, psychological, and social morbidity $^{1-3}$. Although mild and moderate AD can usually be managed with topical treatments and/or phototherapy, approximately $2 \%$ of people with $\mathrm{AD}$ require systemic treatments to induce adequate symptom control ${ }^{4,5}$.

We are entering an exciting era, described by some as a therapeutic revolution ${ }^{6-8}$, as dozens of novel systemic treatments are being developed for AD. These targeted biologic and small molecule agents and the conventional systemic immunosuppressive $\mathrm{AD}$ treatments provide an increasingly broad range of therapeutic options. Although there is some clinical guidance on when to start systemic therapy, many evidence gaps remain regarding the comparative performance of these drugs ${ }^{9,10}$. Moreover, the lack of a gold standard conventional systemic therapy for $\mathrm{AD}$ means there is no benchmark against which to compare the performance of novel agents. Many factors, including the impact on disease severity and quality of life as well as adverse events (AEs) and costeffectiveness, play into the complex treatment decision-making process when clinicians and patients agree on choosing a particular therapy and in the formulation of treatment guidance produced by stakeholders, such as the UK National Institute for Health and Care Excellence (NICE).

Based on a systematic search of the literature, we discuss the latest developments in systemic $\mathrm{AD}$ treatments. We present an indirect comparison of novel and conventional systemic $\mathrm{AD}$ treatments with regard to treatment efficacy, safety, and costeffectiveness and highlight important gaps that need to be filled.

\section{Conventional systemic atopic dermatitis treatments}

The main conventional systemic treatments for $\mathrm{AD}$ are ciclosporin, methotrexate, and azathioprine $e^{11-13}$. Mycophenolate mofetil is less commonly used. Some of these agents have been used to treat severe $\mathrm{AD}$ for decades despite a lack of robust randomised controlled trial (RCT) evidence. Ciclosporin is a calcineurin inhibitor that inhibits T-cell-dependent immune responses. It has a rapid onset of action with significant improvement in disease severity often seen within a few weeks. However, relapse is commonly seen after treatment withdrawal. Methotrexate is a folic acid antagonist, but its exact mechanism of action in inflammatory diseases, including $\mathrm{AD}$, is not fully understood. It has a relatively slow onset of action, like azathioprine. The latter exerts its anti-inflammatory effects by inhibition of de novo purine synthesis leading to impaired leucocyte proliferation. Anecdotally, azathioprine and methotrexate have the potential to alter the natural history of the disease and induce long-term remission, although there is currently no RCT evidence to confirm this ${ }^{14-16}$. Mycophenolate mofetil blocks de novo guanine synthesis via the inhibition of inosine monophosphate dehydrogenase leading to impaired leucocyte proliferation. The safety profiles of azathioprine and ciclosporin in particular are of concern. Nephrotoxicity and hypertension are the most significant side effects of ciclosporin. As a result, the United States Food and Drug Administration recommends limiting its continuous use to one year in psoriasis patients ${ }^{17}$. Azathioprine can cause myelosuppression and carries an increased risk of infection, lymphoma, and non-melanoma skin cancer ${ }^{18-22}$. Methotrexate and mycophenolate mofetil are considered relatively safe medications, but long-term data from $\mathrm{AD}$ cohorts are missing at present. In practice, even when a conventional agent is working well in $\mathrm{AD}$, most clinicians feel that these agents cannot be used for years, particularly because of the long-term risk of malignancy. The development of novel agents, with improved long-term safety, is therefore essential.

\section{Novel systemic atopic dermatitis treatments}

Thanks to our enhanced understanding of the complex immunological processes in $\mathrm{AD}$ skin, there are now many promising treatment targets (Figure 1). Dupilumab is an interleukin (IL)-4 receptor $\alpha$-antagonist that inhibits IL- 4 and IL-13 signalling and has been approved in Europe and the United States for the treatment of adults with moderate-to-severe AD. Clinical trials are underway in children. In addition to dupilumab, the IL-13 inhibitors tralokinumab and lebrikizumab and the IL-31 receptor monoclonal antibody nemolizumab have also demonstrated good potential in clinical trials. Fezakinumab, a monoclonal antibody against IL-22, was effective in the treatment of patients with severe AD in a recent phase 2 trial. Janus kinase (JAK) inhibitors are used to treat a range of inflammatory diseases, and data demonstrating their efficacy in $\mathrm{AD}$ are now also emerging.

\section{Indirect comparison of atopic dermatitis systemic treatments}

As there is a paucity of direct head-to-head trial data comparing treatments in $\mathrm{AD}$, we have indirectly compared the performance of these drugs using data from published RCTs. In our analysis, we have included both blinded and open-label extension RCTs that were published up until 30 September 2018 and report efficacy and safety data of one or more systemic immunomodulatory treatments for moderate-to-severe AD. We have included only the conventional systemic RCTs in which the most commonly used conventional treatments were tested: ciclosporin, methotrexate, azathioprine, and mycophenolate mofetil. We included only trials that used a validated severity measure, such as the Eczema Area and Severity Index (EASI), Scoring Atopic Dermatitis (SCORAD) index, the Six Area Six Sign Atopic Dermatitis (SASSAD) severity score, or the Patient Oriented Eczema Measure (POEM).

\section{Overview of included randomised controlled trials}

We included 33 trials (Table 1). Most of the trials testing conventional systemic agents were small, and a single phase 3 dupilumab trial enrolled more patients than all the included conventional systemic trials ${ }^{23}$. A total of 12 RCTs were headto-head comparisons and 21 were placebo-controlled trials. The majority $(85.7 \%, 12 / 14)$ of the conventional systemic agent trials were head-to-head comparisons, while there are currently no head-to-head trials including novel AD treatments. A diverse range of primary endpoints was used across these studies (Figure 2).

\section{Treatment effectiveness: physician-assessed severity measures}

Different clinical severity score endpoints were reported across the trials (Supplementary Figure 1). Many trials did not report the same scores, even as secondary or experimental endpoints, 


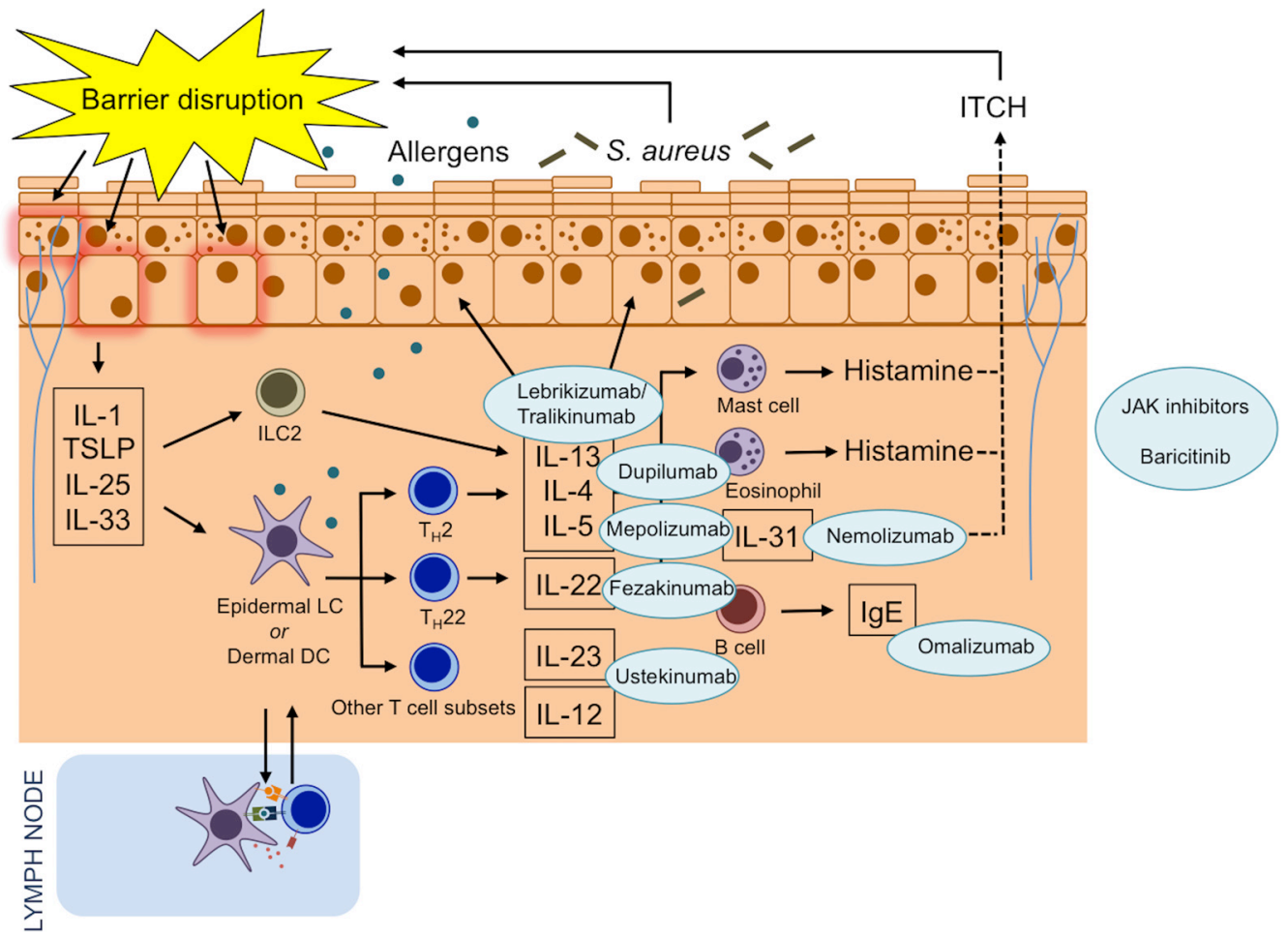

Figure 1. Atopic dermatitis pathogenesis and drug targets of novel systemic therapies. Novel systemic therapies target immune mediators in atopic dermatitis. Mepolizumab is a monoclonal antibody to interleukin-4 (IL-4). Omalizumab is a monoclonal antiimmunoglobulin E (IgE) antibody. Dupilumab is an IL-4 receptor $\alpha$-antagonist that inhibits IL-4 and IL-13 signalling. Lebrikizumab and tralokinumab are monoclonal antibodies that bind to IL-13. Ustekinumab binds to the shared p40 subunit of IL-12 and IL-23 to regulate T helper type 1 (Th1) and Th17 pathways. Nemolizumab is a monoclonal antibody against IL-31 receptor A. Fezakinumab is an IL-22 antagonist. Baricitinib is a Janus kinase 1 (JAK1) and JAK2 inhibitor. DC, dendritic cell; ILC2, type 2 innate lymphoid cell; LC, Langerhans cell; S. aureus, Staphylococcus aureus; TSLP, thymic stromal lymphopoietin.

making indirect comparison of some treatments very difficult. In some cases, the scales of the same score differed across trials, thus further complicating clinical effectiveness comparisons. For instance, the Investigator's Global Assessment (IGA) score was reported in 22 trials, but some used a five-point Likert scale while others used a six-point scale. Some trials reported the objective SCORAD score, whereas others published the full composite SCORAD index, which includes patient-reported pruritus and sleep disturbance.

We compared the mean percentage change from baseline for EASI and SCORAD for each of the systemic treatments where these data were available (Figure 3a and 3b, Supplementary Figure 2a and $2 \mathrm{~b}$ ). We calculated a mean placebo response using pooled data from all novel systemic therapy RCTs. This indirect comparison suggests that ciclosporin at a dose of $2.7-5 \mathrm{mg} / \mathrm{kg} /$ day in the short-term and methotrexate and azathioprine in the longer term may perform as well as many of the novel systemic agents. The superior performance of dupilumab compared with ciclosporin $(2.5-5 \mathrm{mg} / \mathrm{kg} / \mathrm{day})$ in terms of EASI is consistent with another indirect comparison in which logistic regression modelling was used to predict the EASI responses to these treatments ${ }^{24}$.
However, drug dosing is important, and an indirect comparison of effectiveness, as measured by SCORAD reduction induced by these agents, suggests that ciclosporin at a dose of $5 \mathrm{mg} / \mathrm{kg} /$ day may be as effective as dupilumab at least for short-term disease control.

\section{Treatment effectiveness: patient-reported severity measures}

A wide range of patient-assessed measures was reported across the included trials (Supplementary Figure 3). Nemolizumab and dupilumab appear to be superior in improving pruritus compared to the other treatments (Figure 4), although the available pruritus score data are very limited, in particular for conventional systemic agents.

Treatment effectiveness: quality of life

The Dermatology Life Quality Index (DLQI) was the most widely reported measure of quality of life, although there were several other scores reported across the trials (Supplementary Figure 4). Baricitinib and dupilumab appear to perform best at improving quality of life (Figure 5), although DLQI was not reported in most 
Table 1. Summary of included randomised controlled trials.

\begin{tabular}{|c|c|c|c|c|}
\hline Author & Year & Intervention & $\mathbf{n}$ & $\begin{array}{l}\text { Study } \\
\text { duration } \\
\text { (weeks) }\end{array}$ \\
\hline Harper et al..$^{25}$ & 2000 & $\begin{array}{l}\text { Ciclosporin burst versus } \\
\text { continuous therapy }\end{array}$ & 40 & 52 \\
\hline Granlund et al. ${ }^{26}$ & 2001 & $\begin{array}{l}\text { Ciclosporin versus UVAB } \\
\text { phototherapy }\end{array}$ & 38 & 8 \\
\hline Pacor et al. ${ }^{27}$ & 2004 & Ciclosporin versus tacrolimus & 30 & 8 \\
\hline Bemanian et al. ${ }^{28}$ & 2005 & $\begin{array}{l}\text { Ciclosporin versus intravenous } \\
\text { immunoglobulin }\end{array}$ & 14 & 12 \\
\hline Schmitt et al. ${ }^{29}$ & 2010 & Ciclosporin versus prednisolone & 38 & 6 \\
\hline El-Khalawany et al. ${ }^{30}$ & 2013 & Ciclosporin versus methotrexate & 40 & 12 \\
\hline Koppelhus et al. ${ }^{31}$ & 2014 & $\begin{array}{l}\text { Ciclosporin versus extracorporeal } \\
\text { photopheresis }\end{array}$ & 20 & 30 \\
\hline Jin et al..$^{32}$ & 2015 & $\begin{array}{l}\text { Ciclosporin versus ciclosporin }+ \\
\text { glucosamine }\end{array}$ & 38 & 8 \\
\hline Kim et al. ${ }^{33}$ & 2016 & $\begin{array}{l}\text { Ciclosporin versus ciclosporin }+ \\
\text { topical therapy }\end{array}$ & 60 & 24 \\
\hline Goujon et al. ${ }^{34}$ & 2017 & Ciclosporin versus methotrexate & 97 & 24 \\
\hline Berth-Jones et al. ${ }^{35}$ & 2002 & Azathioprine versus placebo & 27 & 12 \\
\hline Meggitt et al. ${ }^{36}$ & 2006 & Azathioprine versus placebo & 41 & 12 \\
\hline Schram et al. ${ }^{37}$ & 2011 & Azathioprine versus methotrexate & 42 & 12 \\
\hline Gerbens et al. ${ }^{14}$ & 2018 & Azathioprine versus methotrexate & 35 & 260 \\
\hline Oldhoff et al. ${ }^{38}$ & 2005 & Mepolizumab versus placebo & 43 & 2 \\
\hline lyengar et al..$^{39}$ & 2013 & Omalizumab versus placebo & 8 & 24 \\
\hline Beck et al. ${ }^{40}$ & 2014 & Dupilumab versus placebo & 30 & 4 \\
\hline Beck et al. ${ }^{40}$ & 2014 & Dupilumab versus placebo & 37 & 4 \\
\hline Beck et al. ${ }^{40}$ & 2014 & Dupilumab versus placebo & 109 & 12 \\
\hline Beck et al..$^{40}$ & 2014 & $\begin{array}{l}\text { Dupilumab + topical } \\
\text { glucocorticoids versus placebo }\end{array}$ & 31 & 4 \\
\hline Thaçi et al. ${ }^{41}$ & 2016 & Dupilumab versus placebo & 379 & 16 \\
\hline Simpson et al. ${ }^{23}$ & 2016 & Dupilumab versus placebo & 671 & 16 \\
\hline Simpson et al. ${ }^{23}$ & 2016 & Dupilumab versus placebo & 708 & 16 \\
\hline Blauvelt et al. ${ }^{42}$ & 2017 & Dupilumab versus placebo & 740 & 52 \\
\hline de Bruin-Weller et al. ${ }^{43}$ & 2018 & Dupilumab versus placebo & 390 & 16 \\
\hline Khattri et al. ${ }^{44}$ & 2017 & Ustekinumab versus placebo & 33 & 33 \\
\hline Saeki et al. ${ }^{45}$ & 2017 & Ustekinumab versus placebo & 79 & 12 \\
\hline Ruzicka et al. ${ }^{46}$ & 2017 & Nemolizumab versus placebo & 264 & 12 \\
\hline Kabashima et al. ${ }^{47}$ & 2018 & Nemolizumab versus placebo & 191 & 64 \\
\hline Wollenberg et al. ${ }^{48}$ & 2018 & Tralokinumab versus placebo & 204 & 12 \\
\hline Guttman-Yassky et al. ${ }^{49}$ & 2018 & Fezakinumab versus placebo & 60 & 10 \\
\hline Guttman-Yassky et al. ${ }^{50}$ & 2018 & Baricitinib versus placebo & 124 & 16 \\
\hline Simpson et al. ${ }^{51}$ & 2018 & Lebrikizumab versus placebo & 209 & 12 \\
\hline
\end{tabular}




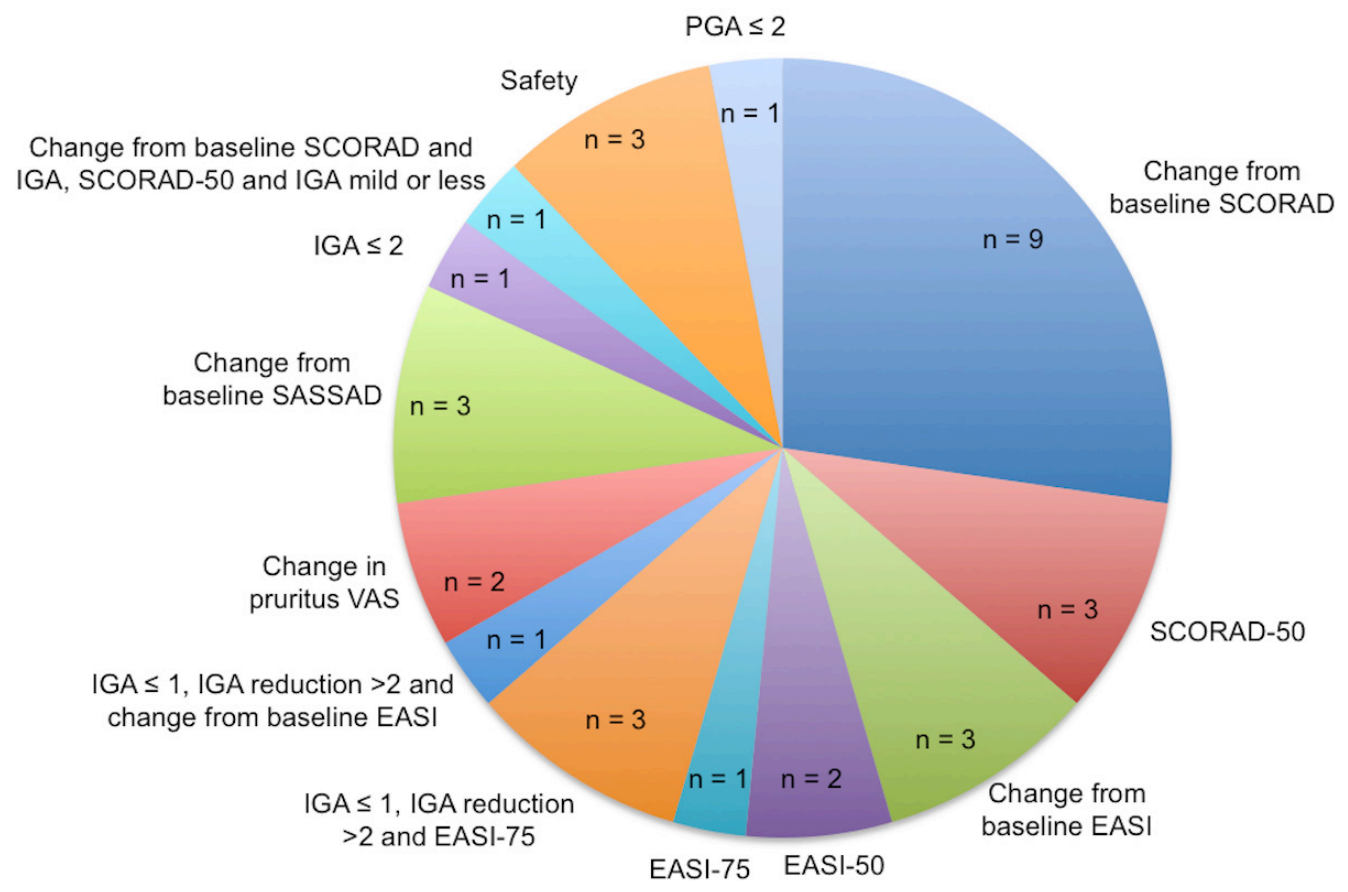

Figure 2. Primary end points of included trials. The diverse range of primary endpoints reported across included randomised controlled trials. EASI, Eczema Area and Severity Index; IGA, Investigator's Global Assessment; PGA, Physician's Global Assessment; SASSAD, Six Area Six Sign Atopic Dermatitis; SCORAD, Scoring Atopic Dermatitis; VAS, visual analogue scale.

of the conventional systemic trials, thus precluding many of these treatments from the comparison.

\section{Treatment effectiveness: long-term disease control}

Regarding long-term disease control, there are very few data available on the performance of conventional systemics and no data beyond 64 weeks for the novel systemic agents. Dupilumab and nemolizumab appear to be superior to other treatments up to one year (Figure 6). Haeck et al. showed that mycophenolate sodium is also effective at maintaining remission for up to one year, after remission was induced with a six-week course of ciclosporin ${ }^{52}$. A five-year follow up study comparing methotrexate and azathioprine was recently published and suggests good long-term effectiveness for both, but patient numbers in each study arm were small $^{14}$. The extension study SOLO-CONTINUE (NCT02395133) will provide even longer-term effectiveness data for dupilumab. Importantly, data on clinical effectiveness in terms of inducing and maintaining disease remission off treatment are lacking for any systemic therapy, although anecdotally this has been seen for methotrexate and azathioprine in particular ${ }^{14-16}$.

\section{Drug safety profiles}

\section{Short-term safety}

To compare the tolerability and safety of AD systemic treatments, we have calculated the incidence rates per participant per week for AEs and serious AEs (SAEs), as these were defined in individual trials $(n=26)$. Seven trials either did not provide any AE data or did not provide the data in a form that enabled incidence rate calculation. This highlights the lack of standardisation in safety reporting in clinical trials, limiting robust comparisons across trials. Table 2 summarises the available safety data from the included studies, showing high variability in the incidence rates reported for the conventional systemic agents. This is most likely due to the small study size and short duration of the included studies. If participant numbers are small in a RCT, then there may be misleadingly low AE reporting, falsely suggesting a more favourable drug safety profile than is seen in clinical practice.

\section{Long-term safety}

Although pre-clinical data suggest that novel systemics may be safer than conventional agents, data on the long-term safety of both systemics in $\mathrm{AD}$ populations are limited ${ }^{53}$. Although most cases of immunosuppression-related malignancy occur in the context of organ transplantation, studies of patients with inflammatory bowel disease have found an increased risk of lymphoma and non-melanoma skin cancer in those treated with azathioprine ${ }^{19-22}$. Furthermore, there are cases of methotrexateassociated lymphoproliferative disorders, which resolve after withdrawal of the drug, seen in adults with autoimmune diseases, such as rheumatoid arthritis ${ }^{54,55}$. However, these patients have different co-morbidities and take additional medications to those taken by $\mathrm{AD}$ patients, which may play a role in these associations. Cases of malignancy have been reported in RCTs of JAK inhibitors in patients with rheumatoid arthritis, and additional data from long-term follow up of patient cohorts is needed to determine the true malignancy risk for JAK inhibitors in $\mathrm{AD}^{56}$. 


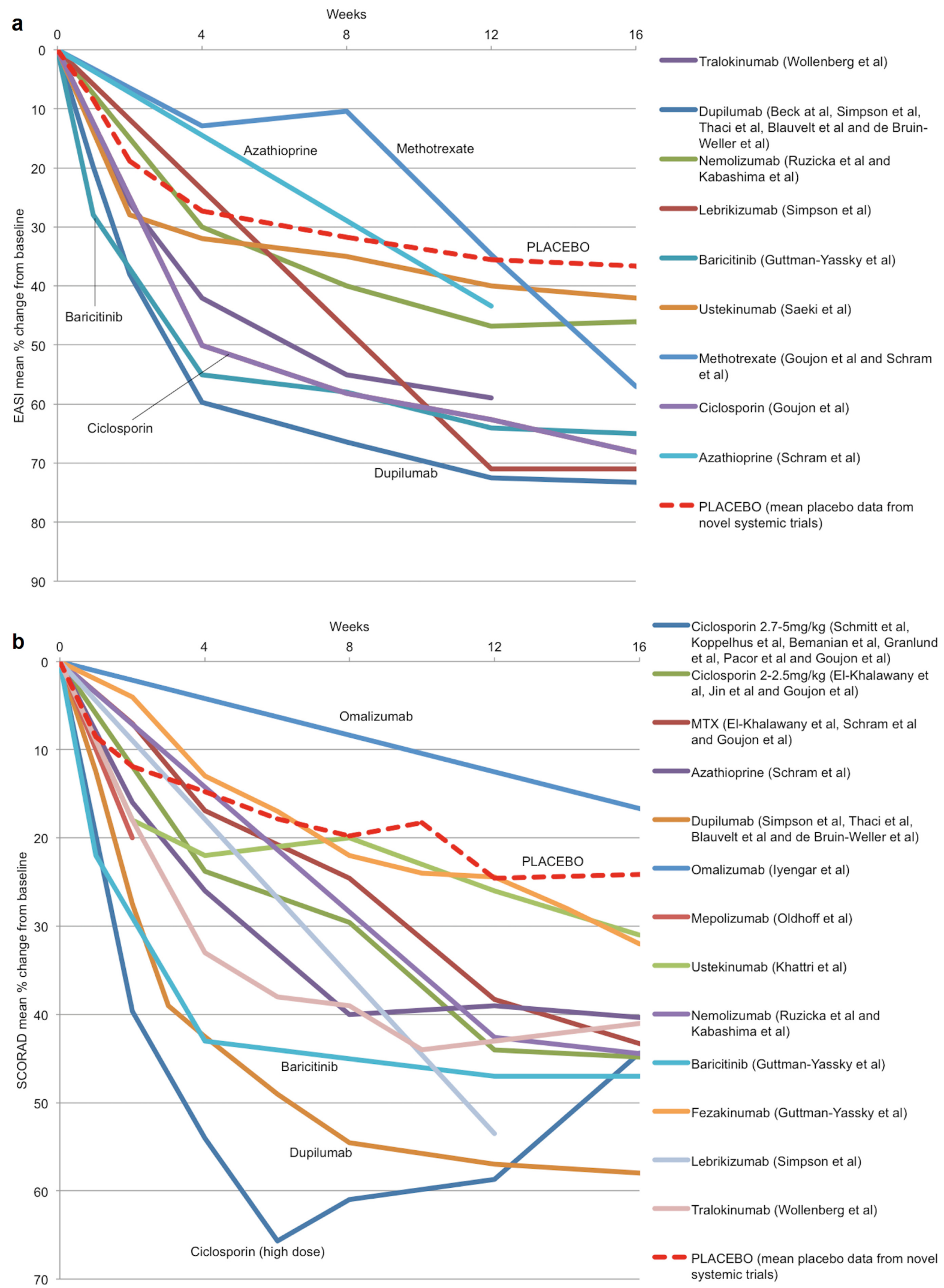

Figure 3. Treatment effectiveness: physician-assessed severity measures. Eczema Area and Severity Index (EASI) (a) and Scoring Atopic Dermatitis (SCORAD) (b) mean percentage change from baseline up to 16 weeks for systemic agents for which these data were reported. MTX, methotrexate. 


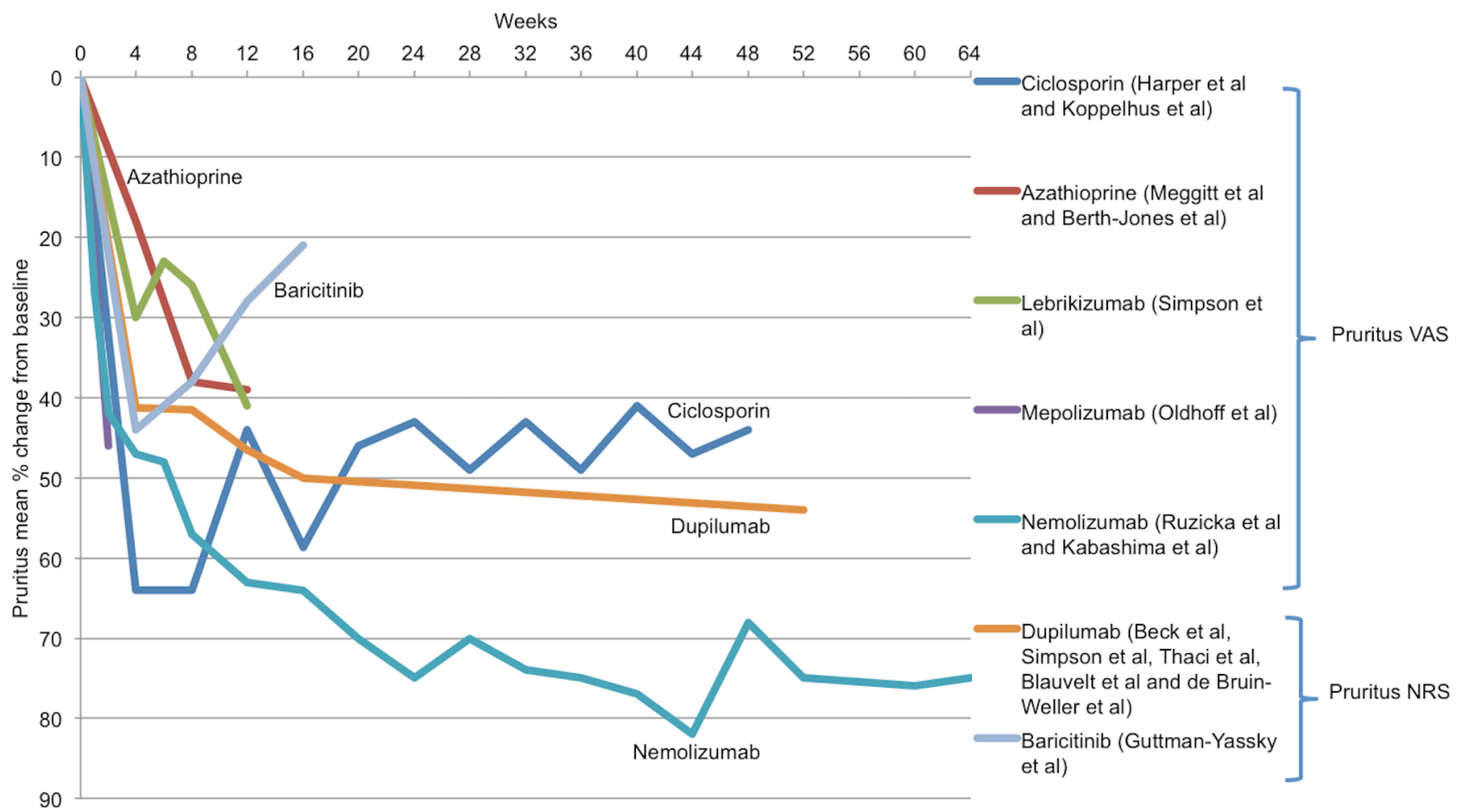

Figure 4. Treatment effectiveness: patient-reported severity measures. Mean percentage change from baseline in pruritus visual analogue score (VAS) and pruritus numerical rating scale (NRS) for systemic agents for which these data were reported.

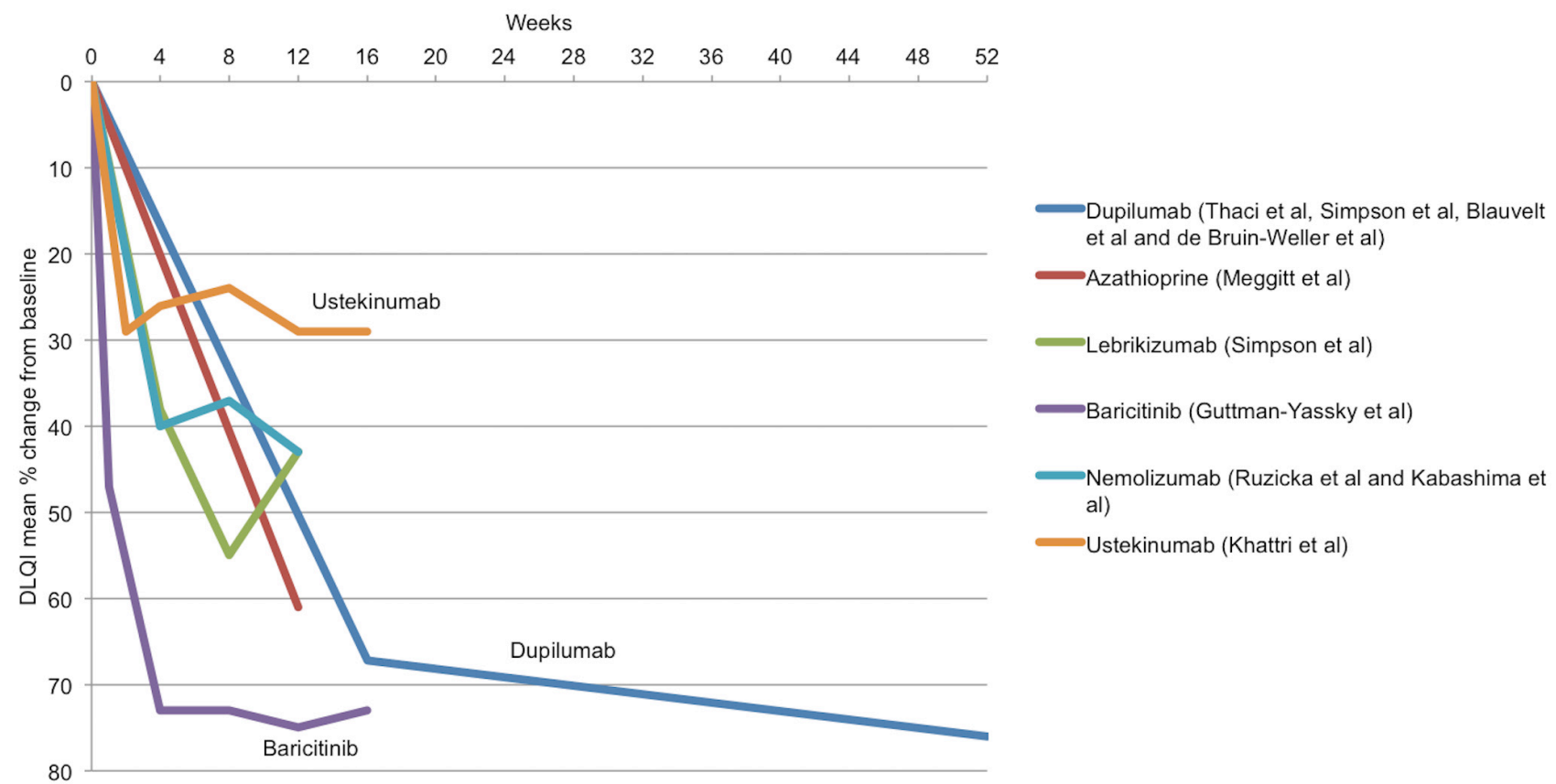

Figure 5. Treatment effectiveness: quality of life. Dermatology Life Quality Index (DLQI) mean percentage change from baseline for systemic agents for which these data were reported. 
Weeks

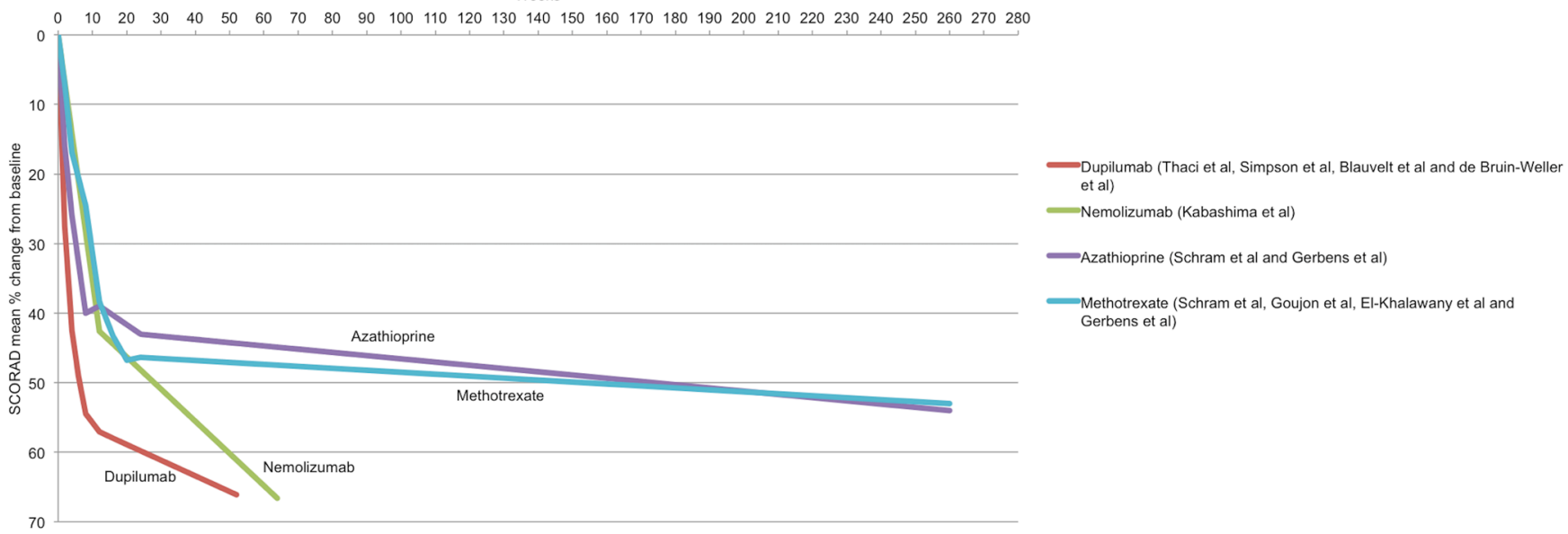

Figure 6. Treatment effectiveness: long-term disease control. Scoring Atopic Dermatitis (SCORAD) mean percentage change from baseline for systemic agents for which these data were reported in at least one trial that was one year or longer in duration.

\section{Table 2. Summary of adverse events.}

\begin{tabular}{|c|c|c|c|}
\hline $\begin{array}{l}\text { Systemic } \\
\text { agent }\end{array}$ & $\begin{array}{l}\text { SAE incidence } \\
\text { rate per patient } \\
\text { week }(\%)\end{array}$ & $\begin{array}{l}\text { AE incidence rate per } \\
\text { patient week }(\%)\end{array}$ & Common AEs (clinical trial incidence of $\geq 1 / 100$ ) \\
\hline Ciclosporin & $0-2.2$ & 0-20.8 & $\begin{array}{l}\text { Serum creatinine increase, hypertension, GI upset, infections, skin } \\
\text { infections, headache, fatigue, cramps, paraesthesia, lower limb } \\
\text { oedema, hypertrichosis, gingival hyperplasia, anaemia, leukopenia, } \\
\text { pancytopenia, thrombocytopenia, ESR increase, liver enzyme increase, } \\
\text { magnesium decrease, fever, malaise, AD exacerbation, dyslipidaemia, } \\
\text { tremor, flushing, metallic taste }\end{array}$ \\
\hline Methotrexate & 0.19 & $9.8-23.5$ & $\begin{array}{l}\text { GI upset, infections, liver enzyme increase, skin infections, AD } \\
\text { exacerbation, anaemia, leukopenia, pancytopenia, fatigue, headache, } \\
\text { renal impairment, fever, malaise }\end{array}$ \\
\hline Azathioprine & 0.03 & 3-22.9 & $\begin{array}{l}\text { GI upset, URTI, LRTI, fatigue, light-headedness, malaise, headache, } \\
\text { folliculitis, skin infections, lymphopenia, neutropenia, liver enzyme } \\
\text { increase, AD exacerbation }\end{array}$ \\
\hline $\begin{array}{l}\text { Mycophenolate } \\
\text { mofetil }\end{array}$ & 0 & 4.2 & $\begin{array}{l}\text { Nausea, headache, fatigue, paraesthesia, muscle ache, infections, } \\
\text { serum creatinine increase, leukopenia, liver enzyme increase, } \\
\text { magnesium decrease }\end{array}$ \\
\hline Dupilumab & $0-0.55$ & $6.4-21.6$ & $\begin{array}{l}\text { Nasopharyngitis, headache, URTI, injection site reactions, } \\
\text { conjunctivitis, AD exacerbation, skin infections, herpes viral infections }\end{array}$ \\
\hline Nemolizumab & 0.18 & 6.6 & $\begin{array}{l}\text { Nasopharyngitis, AD exacerbation, serum CK increase, URTI, } \\
\text { headache, peripheral oedema, impetigo, injection-site reactions }\end{array}$ \\
\hline Ustekinumab & 0 & $2.3-2.4$ & Nasopharyngitis, AD exacerbation \\
\hline Fezakinumab & 0.42 & 2.25 & Viral URTI \\
\hline Lebrikizumab & $\begin{array}{l}\text { Not reported } \\
(3.2 \% \text { of patients } \\
\text { had } \geq 1 \text { SAE over } \\
20 \text {-week study) }\end{array}$ & $\begin{array}{l}\text { Not reported } \\
(67 \% \text { of patients had } \geq 1 \\
\text { AE over } 20 \text {-week study) }\end{array}$ & $\begin{array}{l}\text { Infections, skin infections, HSV and HZV infections, } \\
\text { conjunctivitis, injection site reactions }\end{array}$ \\
\hline Baricitinib & $0.08 \%$ & $\begin{array}{l}\text { Not reported } \\
\text { (59\% of patients had } \geq 1 \\
\text { AE over } 16 \text {-week study) }\end{array}$ & $\begin{array}{l}\text { Headache, serum CK increase, AD exacerbation, nasopharyngitis, } \\
\text { cellulitis, infections }\end{array}$ \\
\hline Tralokinumab & $\begin{array}{l}\text { Not reported } \\
\text { (3.3\% of patients } \\
\text { had } \geq 1 \text { SAE over } \\
12 \text {-week study) }\end{array}$ & $\begin{array}{l}\text { Not reported } \\
(66 \% \text { of patients had } \geq 1 \\
\text { AE over } 12 \text {-week study) }\end{array}$ & $\begin{array}{l}\text { Nasopharyngitis, URTI, headache, AD exacerbation, injection site } \\
\text { reactions, arthralgia, syncope }\end{array}$ \\
\hline
\end{tabular}

$\mathrm{AD}$, atopic dermatitis; AE, adverse event; CK, creatine kinase; ESR, erythrocyte sedimentation rate; GI, gastrointestinal; HSV, herpes simplex virus; HZV, herpes zoster virus; LRTI, lower respiratory tract infection; SAE, serious adverse event; URTI, upper respiratory tract infection. 


\section{Cost-effectiveness}

Despite novel systemic agents' promising clinical effectiveness, there is no guarantee that they will be affordable for use within collectively funded healthcare systems. Given that innovations in medicine often impose additional costs when compared to usual care, many healthcare systems around the world now require robust evidence demonstrating that a drug therapy is cost-effective to receive approval for use in clinical practice ${ }^{57,58}$. As such, it is important to consider the evidence needed to develop a costeffectiveness analysis when formulating data collection strategies for the evaluation of novel systemic treatments. In many countries-including England, Canada, and Australiacost-effectiveness studies quantify changes in patient health, using the quality-adjusted life year (QALY), which combines mortality and morbidity effects in a single outcome measure ${ }^{59-61}$. Morbidity effects are typically captured using a preference-based measure of health-related quality of life (HRQoL), such as the EQ-5D instrument ${ }^{62}$. In addition, data on healthcare resource use and unit costs are needed to calculate the expected healthcare costs associated with the alternative treatments being compared.

A recent systematic review by McManus et al. identified 24 cost-effectiveness studies evaluating interventions for the treatment and prevention of $\mathrm{AD}^{63}$. One of the key findings in this review was the observed variability in the methods used to combine different forms of evidence (e.g. response rates, HRQoL effects, and resource use), also known as models. In other disease areas, such as rheumatoid arthritis and psoriatic arthritis ${ }^{64}$, efforts have been made to reach a consensus on the preferred modelling approach and, as a consequence, standardise the evidence requirements. Similar efforts to establish a preferred modelling approach in the context of AD not only would provide a benchmark against which studies could be assessed but also could be used to inform future data collection strategies.

Another important finding of the systematic review was that the time horizons under examination in many of the studies were of insufficient duration. Ideally, the time horizon for any given cost-effectiveness study should reflect the length of time over which the expected costs and QALYs are likely to differ between alternative treatment strategies ${ }^{65}$. Although a challenging proposition given that the follow up of patients even in observational studies continues for only three to five years, the recent appraisal of dupilumab by NICE demonstrates that observational evidence can be used in addition to RCT data to inform the cost-effectiveness analysis of patients ${ }^{66}$. Partly based on this health economic analysis, NICE has recommended dupilumab as an option for treating moderate-to-severe $\mathrm{AD}$ in adults where the disease has not responded to at least one conventional systemic therapy or where these are contraindicated or not tolerated ${ }^{66}$. Interestingly, the economic model considered as part of the NICE appraisal compared dupilumab with topical therapy as best supportive care. The rationale for this was that dupilumab would be positioned after conventional systemics in the treatment pathway for $\mathrm{AD}$, at which point the only other treatment option for patients would be topical therapy ${ }^{67}$. Topical therapy might indeed be considered best supportive care once a patient has failed on all conventional systemics; however, this was not the population of patients studied in the dupilumab trials. Indeed, only one trial, LIBERTY-CAFÉ, required participants to have a prior history of ciclosporin use (or contraindication). It is likely that the effectiveness of topical treatment varies in different populations and would be expected to be lower in a population of patients with $\mathrm{AD}$ who have failed multiple systemic treatments compared to those who are systemic treatment naïve. A cost-effectiveness model for novel agents should therefore be compared to conventional systemic treatment as best supportive care, even if this is challenging given the current lack of data on the cost-effectiveness of conventional systemics.

The formation of the UK-Irish Atopic eczema Systemic Therapy Register (A*STAR) and other national AD registers within the international TREatment of ATopic eczema registry taskforce (TREAT) represents an important milestone in the collection of data that can be used to inform cost-effectiveness studies for the evaluation of novel AD therapies ${ }^{68,69}$. These treatment registers will be an important data source for the development of future appraisal submissions to regulatory bodies, such as NICE in the UK, given that they collect longitudinal disease severity, quality of life, and healthcare resource use data for every patient recruited and compare conventional and novel therapies alike.

\section{Indirect comparison method limitations}

The indirect comparison of clinical effectiveness, safety data, and cost-effectiveness drawn from different studies, as presented here, has important limitations. Such comparisons lose the benefits derived from randomisation, such as the balancing of effect modifiers across treatment groups at baseline. Whilst direct comparisons from individual studies may have a low risk of bias (i.e. high internal validity), the inferences drawn from comparisons between studies must be considered observational data and are therefore at higher risk of bias. For example, if the baseline characteristics of the trial participants, such as disease severity, differ, then it is difficult to compare a change in disease severity across trials even where the same disease severity measure was used. Other study design differences will additionally impact on treatment effectiveness, such as the use of concomitant topical corticosteroids.

\section{Where do we go from here?}

Further head-to-head active comparator studies are needed, such as the ongoing TREatment of severe Atopic eczema Trial (TREAT), which compares ciclosporin and methotrexate in children with moderate-to-severe $\mathrm{AD}^{70}$. Such studies need to use validated outcome measures that are harmonised to allow for comparisons to be made across studies. The Harmonising Outcome Measures for Eczema (HOME) initiative is an international effort towards a core outcome set for clinical trials in AD that will help to facilitate this $^{71}$. Whilst not a current aim of the HOME initiative, reporting would also be useful.

Recognising that randomised controlled trial data directly comparing active treatments will always be limited, network metaanalysis (NMA) will be helpful in plugging this evidence gap. NMA is an approach whereby direct and indirect data can be combined into a single statistical model that takes into account 
variations between studies and where the assumptions around the similarities between studies can be evaluated ${ }^{72}$.

Although novel systemic agents may not vastly improve the clinical effectiveness outcomes in $\mathrm{AD}$, they have the potential to address the more pressing clinical issue of short- and long-term AEs secondary to $\mathrm{AD}$ treatment. The limited duration of clinical trials, relatively small sample sizes with respect to safety outcomes, and issues around the generalisability of their findings to the wider patient population mean that data from large 'real-world' studies, such as registers and electronic health records, will play an important role in providing evidence to support clinical decisionmaking. Standardised AE reporting is also needed as we approach an era where safety and tolerability may become more of a differentiator of treatments than clinical effectiveness.

\section{Conclusion}

Novel biologic and small molecule agents provide great promise for patients with moderate-to-severe $\mathrm{AD}$. While the clinical effectiveness data from these placebo-controlled RCTs are promising, important factors in addition to short- and long-term treatment effectiveness need to be considered, such as drug safety and cost-effectiveness as well as the ability of a drug to alter the natural history of AD. While evidence generation through head-to-head trials would be the preferred route, such trials are likely to remain low in number. Treatment registers and NMA provide important additional tools to better inform evidence-based treatment decisions made by physicians, patients, and regulatory bodies alike. We have entered an exciting era in AD therapeutics but need to travel a much longer journey before the promise of a therapeutic revolution becomes a reality.

\section{Abbreviations}

AD, atopic dermatitis; AE, adverse event; DLQI, Dermatology Life Quality Index; EASI, Eczema Area and Severity Index; HOME, Harmonising Outcome Measures for Eczema; HRQoL, healthrelated quality of life; IL, interleukin; JAK, Janus kinase; NICE, National Institute for Health and Care Excellence; NMA, network meta-analysis; QALY, quality-adjusted life year; RCT, randomised controlled trial; SAE, serious adverse event; SCORAD, Scoring Atopic Dermatitis.

\section{Grant information}

CF is funded through a UK National Institute for Health Research (NIHR) Career Development Fellowship (CDF-2014-07-037). CF, HA, and ZKJ-L are supported by the NIHR Biomedical Research Centre based at Guy's and St Thomas' NHS Foundation Trust and King's College London.

The funders had no role in study design, data collection and analysis, decision to publish, or preparation of the manuscript.

\section{Supplementary material}

Supplementary Figure 1. Physician-assessed severity score end points of included trials.

Different clinical severity score endpoints were reported across included randomised controlled trials. Many trials did not report the same scores, making indirect comparison of some treatments very difficult. EASI, Eczema Area and Severity Index; IGA, Investigator's Global Assessment; SASSAD, Six Area Six Sign Atopic Dermatitis; SCORAD, Scoring Atopic Dermatitis.

Click here to access the data

\section{Supplementary Figure 2. Treatment effectiveness: physician-assessed severity measures.}

Eczema Area and Severity Index (EASI) (a) and Scoring Atopic Dermatitis (SCORAD) (b) mean percentage change from baseline up to 64 weeks for systemic agents for which these data were reported. MTX, methotrexate.

Click here to access the data

\section{Supplementary Figure 3. Treatment effectiveness: patient-reported severity measures.}

The number of included trials reporting patient-reported severity measures. HADS, Hospital Anxiety and Depression Scale; NRS, numerical rating scale; POEM, Patient Oriented Eczema Measure; RCT, randomised controlled trial; SCORAD, Scoring Atopic Dermatitis; VAS, visual analogue scale.

Click here to access the data

Supplementary Figure 4. Treatment effectiveness: quality of life.

The number of included trials reporting quality of life measures. AD, atopic dermatitis; cDLQI, children's Dermatology Life Quality Index; DLQI, Dermatology Life Quality Index; RCT, randomised controlled trial; VAS, visual analogue scale. 
1. Deckers IA, McLean S, Linssen S, et al:: Investigating international time trends in the incidence and prevalence of atopic eczema 1990-2010: a systematic review of epidemiological studies. PLoS One. 2012; 7(7): e39803. PubMed Abstract | Publisher Full Text | Free Full Text

2. F Thyssen JP, Hamann CR, Linneberg A, et al:: Atopic dermatitis is associated with anxiety, depression, and suicidal ideation, but not with psychiatric hospitalization or suicide. Allergy. 2018; 73(1): 214-20. PubMed Abstract | Publisher Full Text | F1000 Recommendation

3. Garg N, Silverberg Jl: Association between childhood allergic disease, psychological comorbidity, and injury requiring medical attention. Ann Allergy Asthma Immunol. 2014; 112(6): 525-32. PubMed Abstract | Publisher Full Text

4. McAleer MA, Flohr C, Irvine AD: Management of difficult and severe eczema in childhood. BMJ. 2012; 345: e4770. PubMed Abstract | Publisher Full Text

5. Flohr C, Irvine AD: Systemic therapies for severe atopic dermatitis in children and adults. J Allergy Clin Immunol. 2013; 132(3): 774-774.e6. PubMed Abstract | Publisher Full Text

6. Eichenfield LF, Stein Gold LF: Systemic Therapy of Atopic Dermatitis: Welcome to the Revolution. Sem Cutan Med Surg. 2017; 36(4S): S103-S105. PubMed Abstract | Publisher Full Text

7. Torres T: Atopic Dermatitis: The New Therapeutic Revolution in Dermatology. Acta Med Port. 2017; 30(10): 669-70.

PubMed Abstract | Publisher Full Text

8. Zirwas MJ: The future is finally here: Advances in the treatment of atopic dermatitis. J Am Acad Dermatol. 2018; 78(3 Suppl 1): S25-S27. PubMed Abstract | Publisher Full Text

9. Simpson EL, Bruin-Weller M, Flohr C, et al.: When does atopic dermatitis warrant systemic therapy? Recommendations from an expert panel of the International Eczema Council. J Am Acad Dermatol. 2017; 77(4): 623-33. PubMed Abstract | Publisher Full Text

10. F Seger EW, Wechter T, Strowd L, et al.: Relative efficacy of systemic treatments for atopic dermatitis. J Am Acad Dermatol. 2019; 80(2): 411-416.e4. PubMed Abstract | Publisher Full Text | F1000 Recommendation

11. Totri CR, Eichenfield LF, Logan $\mathrm{K}$, et al:: Prescribing practices for systemic agents in the treatment of severe pediatric atopic dermatitis in the US and Canada: The PeDRA TREAT survey. J Am Acad Dermatol. 2017; 76(2): 281-5. PubMed Abstract | Publisher Full Text

12. Proudfoot LE, Powell AM, Ayis S, et al:: The European TREatment of severe Atopic eczema in children Taskforce (TREAT) survey. Br J Dermatol. 2013; 169(4): 901-9

PubMed Abstract | Publisher Full Text

13. Taylor K, Swan DJ, Affleck A, et al:: Treatment of moderate-to-severe atopic eczema in adults within the U.K.: results of a national survey of dermatologists. Br J Dermatol. 2017; 176(6): 1617-23. PubMed Abstract | Publisher Full Text | Free Full Text

14. Gerbens LAA, Hamann SAS, Brouwer MWD, et al:: Methotrexate and azathioprine for severe atopic dermatitis: a 5-year follow-up study of a randomized controlled trial. Br J Dermatol. 2018; 178(6): 1288-96. PubMed Abstract | Publisher Full Text

15. Hughes $R$, Collins $P$, Rogers $S$ : Further experience of using azathioprine in the treatment of severe atopic dermatitis. Clin Exp Dermatol. 2008; 33(6): 710-1. PubMed Abstract | Publisher Full Text

16. Buckley DA, Baldwin $P$, Rogers $S$ : The use of azathioprine in severe adult atopic eczema. J Eur Acad Dermatol Venerol. 1998; 11(2): 137-40. PubMed Abstract | Publisher Full Text

17. Sidbury R, Davis DM, Cohen DE, et al:: Guidelines of care for the management of atopic dermatitis: section 3 . Management and treatment with phototherapy and systemic agents. J Am Acad Dermatol. 2014; 71(2): 327-49. PubMed Abstract | Publisher Full Text | Free Full Text

18. Roekevisch E, Spuls PI, Kuester D, et al.: Efficacy and safety of systemic treatments for moderate-to-severe atopic dermatitis: a systematic review. J Allergy Clin Immunol. 2014; 133(2): 429-38. PubMed Abstract | Publisher Full Text

19. Armstrong RG, West J, Card TR: Risk of cancer in inflammatory bowel disease treated with azathioprine: a UK population-based case-control study. $A m \mathrm{~J}$ Gastroenterol. 2010; 105(7): 1604-9. PubMed Abstract | Publisher Full Text

20. Singh $\mathrm{H}$, Nugent $\mathrm{Z}$, Demers $\mathrm{AA}$, et al.: Increased risk of nonmelanoma skin cancers among individuals with inflammatory bowel disease. Gastroenterology. 2011; 141(5): 1612-20. PubMed Abstract | Publisher Full Text

21. Beaugerie L, Brousse N, Bouvier AM, et al: Lymphoproliferative disorders in patients receiving thiopurines for inflammatory bowel disease: a prospective observational cohort study. Lancet. 2009; 374(9701): 1617-25. PubMed Abstract | Publisher Full Text

22. Kandiel A, Fraser AG, Korelitz BI, et al:: Increased risk of lymphoma among inflammatory bowel disease patients treated with azathioprine and 6-mercaptopurine. Gut. 2005; 54(8): 1121-5. PubMed Abstract | Publisher Full Text | Free Full Text

23. F Simpson EL, Bieber T, Guttman-Yassky E, et al:: Two Phase 3 Trials of Dupilumab versus Placebo in Atopic Dermatitis. N Engl J Med. 2016; 375(24): 2335-48. PubMed Abstract | Publisher Full Text | F1000 Recommendation

24. Ariens L, Gadkari A, van Os-Medendorp H, et al:: Comparison of the efficacy of dupilumab versus cyclosporine using EASI thresholds in adult patients with moderate to severe atopic dermatitis. In: International Symposium on Atopic Dermatitis. 2018.

25. Harper Jl, Ahmed I, Barclay G, et al.: Cyclosporin for severe childhood atopic dermatitis: Short course versus continuous therapy. Br J Dermatol. 2000; 142(1): 52-8.

PubMed Abstract | Publisher Full Text

26. Granlund $\mathrm{H}$, Erkko $\mathrm{P}$, Remitz A, et al:: Comparison of cyclosporin and UVAB phototherapy for intermittent one-year treatment of atopic dermatitis. Acta Derm Venereol. 2001; 81(1): 22-7.

PubMed Abstract | Publisher Full Text

27. Pacor ML, Di Lorenzo G, Martinelli N, et al:: Comparing tacrolimus ointment and oral cyclosporine in adult patients affected by atopic dermatitis: A randomized study. Clin Exp Allergy. 2004; 34(4): 639-45.

PubMed Abstract | Publisher Full Text

28. Bemanian $\mathrm{MH}$, Movahedi M, Farhoudi $\mathrm{A}$, et al.: High doses intravenous immunoglobulin versus oral cyclosporine in the treatment of severe atopic dermatitis. Iran J Allergy Asthma Immunol. 2005; 4(3): 139-43. PubMed Abstract

29. Schmitt J, Schäkel K, Fölster-Holst R, et al:: Prednisolone vs. ciclosporin for severe adult eczema. An investigator-initiated double-blind placebo-controlled multicentre trial. Br J Dermatol. 2010; 162(3): 661-8.

PubMed Abstract | Publisher Full Text

30. El-Khalawany MA, Hassan H, Shaaban D, et al:: Methotrexate versus cyclosporine in the treatment of severe atopic dermatitis in children: multicenter experience from Egypt. Eur J Pediatr. 2013; 172(3): 351-6. PubMed Abstract | Publisher Full Text

31. Koppelhus U, Poulsen J, Grunnet N, et al:: Cyclosporine and Extracorporeal Photopheresis are Equipotent in Treating Severe Atopic Dermatitis: A Randomized Cross-Over Study Comparing Two Efficient Treatment Modalities. Front Med (Lausanne). 2014; 1: 33. PubMed Abstract | Publisher Full Text | Free Full Text

32. Jin SY, Lim WS, Sung NH, et al:: Combination of glucosamine and low-dose cyclosporine for atopic dermatitis treatment: a randomized, placebocontrolled, double-blind, parallel clinical trial. Dermatol Ther. 2015; 28(1): 44-51. PubMed Abstract | Publisher Full Text

33. F Kim JE, Shin JM, Ko JY, et al:: Importance of concomitant topical therapy in moderate-to-severe atopic dermatitis treated with cyclosporine. Dermatol Ther. 2016; 29(2): 120-5

PubMed Abstract | Publisher Full Text | F1000 Recommendation

34. F Goujon C, Viguier M, Staumont-Sallé D, et al:: Methotrexate Versus Cyclosporine in Adults with Moderate-to-Severe Atopic Dermatitis: A Phase III Randomized Noninferiority Trial. J Allergy Clin Immunol Pract. 2018; 6(2): 562-569.e3.

PubMed Abstract | Publisher Full Text | F1000 Recommendation

35. Berth-Jones J, Takwale A, Tan E, et al:: Azathioprine in severe adult atopic dermatitis: a double-blind, placebo-controlled, crossover trial. Br J Dermatol. 2002; 147(2): 324-30.

PubMed Abstract | Publisher Full Text

36. F Meggitt SJ, Gray JC, Reynolds NJ: Azathioprine dosed by thiopurine methyltransferase activity for moderate-to-severe atopic eczema: a doubleblind, randomised controlled trial. Lancet. 2006; 367(9513): 839-46. PubMed Abstract | Publisher Full Text | F1000 Recommendation

37. F Schram ME, Roekevisch E, Leeflang MM, et al:: A randomized trial of methotrexate versus azathioprine for severe atopic eczema. J Allergy Clin Immunol. 2011; 128(2): 353-9.

PubMed Abstract | Publisher Full Text | F1000 Recommendation

38. Oldhoff JM, Darsow U, Werfel T, et al:: Anti-IL-5 recombinant humanized monoclonal antibody (mepolizumab) for the treatment of atopic dermatitis. Allergy. 2005; 60(5): 693-6.

PubMed Abstract | Publisher Full Text

39. lyengar SR, Hoyte EG, Loza A, et al.: Immunologic effects of omalizumab in children with severe refractory atopic dermatitis: a randomized, placebocontrolled clinical trial. Int Arch Allergy Immunol. 2013; 162(1): 89-93. PubMed Abstract | Publisher Full Text | Free Full Text

40. F Beck LA, Thaçi D, Hamilton JD, et al:: Dupilumab treatment in adults with moderate-to-severe atopic dermatitis. N Engl J Med. 2014; 371(2): 130-9. PubMed Abstract | Publisher Full Text | F1000 Recommendation

41. F Thaçi D, Simpson EL, Beck LA, et al.: Efficacy and safety of dupilumab in 
adults with moderate-to-severe atopic dermatitis inadequately controlled by topical treatments: A randomised, placebo-controlled, dose-ranging phase $2 \mathrm{~b}$ trial. Lancet. 2016; 387(10013): 40-52.

PubMed Abstract | Publisher Full Text | F1000 Recommendation

42. $\mathrm{F}$ Blauvelt $\mathrm{A}$, de Bruin-Weller M, Gooderham M, et al.: Long-term management of moderate-to-severe atopic dermatitis with dupilumab and concomitant topical corticosteroids (LIBERTY AD CHRONOS): A 1-year, randomised, double-blinded, placebo-controlled, phase 3 trial. Lancet. 2017; 389(10086): 2287-2303.

PubMed Abstract | Publisher Full Text | F1000 Recommendation

43. $\mathrm{F}$ de Bruin-Weller $\mathrm{M}$, Thaçi $\mathrm{D}$, Smith $\mathrm{CH}$, et al:: Dupilumab with concomitant topical corticosteroid treatment in adults with atopic dermatitis with an inadequate response or intolerance to ciclosporin $A$ or when this treatment is medically inadvisable: A placebo-controlled, randomized phase III clinical trial (LIBERTY AD CAFÉ). Br J Dermatol. 2018; 178(5): 1083-1101. PubMed Abstract | Publisher Full Text | F1000 Recommendation

44. F Khattri S, Brunner PM, Garcet S, et al.: Efficacy and safety of ustekinumab treatment in adults with moderate-to-severe atopic dermatitis. Exp Dermatol. 2017; 26(1): 28-35.

PubMed Abstract | Publisher Full Text | Free Full Text | F1000 Recommendation

45. F Saeki H, Kabashima K, Tokura Y, et al.: Efficacy and safety of ustekinumab in Japanese patients with severe atopic dermatitis: A randomized, doubleblind, placebo-controlled, phase II study. Br J Dermatol. 2017; 177(2): 419-427. PubMed Abstract | Publisher Full Text | F1000 Recommendation

46. F Ruzicka T, Hanifin JM, Furue M, et al:: Anti-Interleukin-31 Receptor A Antibody for Atopic Dermatitis. N Engl J Med. 2017; 376(9): 826-835. PubMed Abstract | Publisher Full Text | F1000 Recommendation

47. F Kabashima K, Furue M, Hanifin JM, et al:: Nemolizumab in patients with moderate-to-severe atopic dermatitis: Randomized, phase II, long-term extension study. J Allergy Clin Immunol. 2018; 142(4): 1121-1130.e7. PubMed Abstract | Publisher Full Text | F1000 Recommendation

48. F Wollenberg A, Howell MD, Guttman-Yassky E, et al:: Treatment of atopic dermatitis with tralokinumab, an anti-IL-13 mAb. J Allergy Clin Immunol. 2019; 143(1): 135-141.

PubMed Abstract | Publisher Full Text | F1000 Recommendation

49. F Guttman-Yassky E, Brunner PM, Neumann AU, et al:: Efficacy and safety of fezakinumab (an IL-22 monoclonal antibody) in adults with moderate-tosevere atopic dermatitis inadequately controlled by conventional treatments: A randomized, double-blind, phase 2a trial. J Am Acad Dermatol. 2018; 78(5): 872-881.e6.

PubMed Abstract | Publisher Full Text | F1000 Recommendation

50. $\quad \mathrm{F}$ Guttman-Yassky E, Silverberg JI, et al.: Baricitinib in adult patients with moderate-to-severe atopic dermatitis: A phase 2 parallel, double-blinded, randomized placebo-controlled multiple-dose study. J Am Acad Dermatol. 2018; pii: S0190-9622(18)30129-4

PubMed Abstract | Publisher Full Text | F1000 Recommendation

51. F Simpson EL, Flohr C, Eichenfield LF, et al.: Efficacy and safety of lebrikizumab (an anti-IL-13 monoclonal antibody) in adults with moderate-tosevere atopic dermatitis inadequately controlled by topical corticosteroids: $\mathrm{A}$ randomized, placebo-controlled phase II trial (TREBLE). J Am Acad Dermatol. 2018; 78(5): 863-871.e11.

PubMed Abstract | Publisher Full Text | F1000 Recommendation

52. Haeck IM, Knol MJ, Ten Berge O, et al.: Enteric-coated mycophenolate sodium versus cyclosporin A as long-term treatment in adult patients with severe atopic dermatitis: a randomized controlled trial. J Am Acad Dermatol. 2011; 64(6): 1074-84

PubMed Abstract | Publisher Full Text

53. F Braddock M, Hanania NA, Sharafkhaneh A, et al.: Potential Risks Related to Modulating Interleukin-13 and Interleukin-4 Signalling: A Systematic Review. Drug Saf. 2018; 41(5): 489-509.

PubMed Abstract | Publisher Full Text | Free Full Text | F1000 Recommendation

54. Clarke LE, Junkins-Hopkins J, Seykora JT, et al:: Methotrexate-associated lymphoproliferative disorder in a patient with rheumatoid arthritis presenting in the skin. J Am Acad Dermatol. 2007; 56(4): 686-90.

PubMed Abstract | Publisher Full Text

55. Maruani A, Wierzbicka E, Machet MC, et al.: Reversal of multifocal cutaneous lymphoproliferative disease associated with Epstein-Barr virus after withdrawal of methotrexate therapy for rheumatoid arthritis. J Am Acad Dermatol. 2007; 57(5 Suppl): S69-71.

PubMed Abstract | Publisher Full Text

56. Lopez-Olivo MA, Tayar JH, Zamora NV, et al.: Malignancies and serious infections in randomised controlled trials of janus kinase inhibitors in patients with rheumatoid arthritis: a systematic review and meta-analysis. Ann Rheum Dis. 2018; 77(Suppl 2): 66.

Publisher Full Text

57. Drummond M: Future Prospects for Pharmacoeconomics and Outcomes Research in the Emerging Regions. Value Health Reg Issues. 2013; 2(1): 3-4. PubMed Abstract | Publisher Full Text

58. Drummond M: Twenty years of using economic evaluations for drug reimbursement decisions: what has been achieved? J Health Polit Policy Law. 2013; 38(6): 1081-102.

PubMed Abstract | Publisher Full Text

59. National Institute for Health and Care Excellence: Guide to the methods of technology appraisal 2013 [Internet]. National Institute for Health and Care Excellence. 2013; 1-93.

PubMed Abstract

60. Lee KM, McCarron CE, Bryan S, et al.: Guidelines for the economic evaluation of health technologies: Canada. 2017; 1-76. Reference Source

61. Pharmaceutical Benefits Advisory Committee (PBAC), Australian Government Department Of Health: Health AGD of Guidelines for preparing a submission to the Pharmaceutical Benefits Advisory Committee. 2016; 1-205. Reference Source

62. Dolan P: Modeling Valuations for EuroQol Health States. Med Care. 1997; 35(11): 1095-108.

PubMed Abstract | Publisher Full Text

63. F McManus E, Sach T, Levell N: The Use of Decision-Analytic Models in Atopic Eczema: A Systematic Review and Critical Appraisal. Pharmacoeconomics. 2018; 36(1): 51-66

PubMed Abstract | Publisher Full Text | F1000 Recommendation

64. Madan J, Ades T, Barton P, et al.: Consensus Decision Models for Biologics in Rheumatoid and Psoriatic Arthritis: Recommendations of a Multidisciplinary Working Party. Rheumatol Ther. 2015; 2(2): 113-125.

PubMed Abstract | Publisher Full Text | Free Full Text

65. Sculpher MJ, Claxton K, Drummond M, et al.: Whither trial-based economic evaluation for health care decision making? Health Econ. 2006; 15(7): 677-87. PubMed Abstract | Publisher Full Text

66. National Institute for Health and Care Excellence: Dupilumab for treating moderate to severe atopic dermatitis. 2018.

Reference Source

67. NICE: Dupilumab for treating moderate to severe atopic dermatitis [Internet]. Technology appraisal guidance [TA534]. 2018.

Reference Source

68. Gerbens LAA, Apfelbacher CJ, Irvine AD, et al: TREatment of ATopic eczema (TREAT) Registry Taskforce: an international Delphi exercise to identify a core set of domains and domain items for national atopic eczema photo- and systemic therapy registries. Br J Dermatol. 2018.

PubMed Abstract | Publisher Full Text

69. Spuls PI, Gerbens LAA, Apfelbacher CJ, et al.: The International TREatment of ATopic Eczema (TREAT) Registry Taskforce: An Initiative to Harmonize Data Collection across National Atopic Eczema Photo- and Systemic Therapy Registries. J Invest Dermatol. 2017; 137(9): 2014-2016.

PubMed Abstract | Publisher Full Text

70. Irvine $\mathrm{AD}$, Jones $\mathrm{AP}$, Beattie $\mathrm{P}$, et al:: A randomized controlled trial protocol assessing the effectiveness, safety and cost-effectiveness of methotrexate vs. ciclosporin in the treatment of severe atopic eczema in children: The TREatment of severe Atopic eczema Trial (TREAT). Br J Dermatol. 2018; 179(6): 1297-1306.

PubMed Abstract | Publisher Full Text

71. F Schmitt J, Spuls PI, Thomas KS, et al.: The Harmonising Outcome Measures for Eczema (HOME) statement to assess clinical signs of atopic eczema in trials. J Allergy Clin Immunol. 2014; 134(4): 800-7. PubMed Abstract | Publisher Full Text | F1000 Recommendation

72. Chaimani A, Higgins JP, Mavridis D, et al.: Graphical tools for network metaanalysis in STATA. PLoS One. 2013; 8(10): e76654. PubMed Abstract | Publisher Full Text | Free Full Text 


\section{Open Peer Review}

\section{Current Peer Review Status:}

\section{Editorial Note on the Review Process}

Faculty Reviews are review articles written by the prestigious Members of Faculty Opinions. The articles are commissioned and peer reviewed before publication to ensure that the final, published version is comprehensive and accessible. The reviewers who approved the final version are listed with their names and affiliations.

\section{The reviewers who approved this article are:}

\section{Version 1}

\section{Steven R Feldman}

Department of Dermatology, Wake Forest School of Medicine, Winston-Salem, USA Competing Interests: Feldman has received research, speaking and/or consulting support from a variety of companies including Galderma, GSK/Stiefel, Almirall, Leo Pharma, BMS, Boehringer Ingelheim, Mylan, Celgene, Pfizer, Ortho Dermatology, Abbvie, Samsung, Janssen, Lilly, Menlo, Merck, Novartis, Regeneron, Sanofi, Novan, Qurient, National Biological Corporation, Caremark, Advance Medical, Sun Pharma, Suncare Research, Informa, UpToDate and National Psoriasis Foundation

\section{Gil Yosipovitch}

Department of Dermatology and Cutaneous surgery and Itch Center, Miller School of Medicine, University of Miami, Miami, USA

Competing Interests: No competing interests were disclosed.

3. Robert Sidbury

Dermatology Division, Seattle Children's Hospital, Seattle, USA

Competing Interests: No competing interests were disclosed. 
The benefits of publishing with F1000Research:

- Your article is published within days, with no editorial bias

- You can publish traditional articles, null/negative results, case reports, data notes and more

- The peer review process is transparent and collaborative

- Your article is indexed in PubMed after passing peer review

- Dedicated customer support at every stage

For pre-submission enquiries, contact research@f1000.com 